\title{
Synthesis, Spectroscopy and Electrochemistry of New 3-(5-Aryl-4,5-Dihydro-1H-Pyrazol-3-yl)-4-Hydroxy-2H- Chromene-2-One 4, 5 as a Novel Class of Potential Anti- bacterial and Antioxidant Derivatives
}

\author{
Abdullah Sulaiman Al-Ayed \\ College of Science and Arts at Ar-Rass, Qassim University, Kingdom of Saudi Arabia \\ E-mail: salayedabdualla1@yahoo.com \\ Received June 24, 2011; revised August 1, 2011; accepted August 10, 2011
}

\begin{abstract}
3-((2E)-3(aryl)prop-2-enoyl)-2H-chromen-2-one 3 was synthesized from 4-hydroxy coumarin by refluxing 3-acetyl-4-hydroxy coumarin with aromatic aldehydes in chloroform in the presence of a catalytic amount of piperidine. 3 was converted to pyrazoles $\mathbf{4 , 5}$ by treatment with hydrazine and phenylhydrazine in toluene, respectively. The structures of the new compounds were confirmed by elemental analysis, IR, and multinuclear/multidimensional NMR spectroscopy $\left({ }^{1} \mathrm{H},{ }^{13} \mathrm{C}-\mathrm{NMR}\right.$, NOESY, HMBC) which allowed us to assign the complete network of proton and carbon atoms. All the compounds exhibited one quasireversible redox process. All the newly synthesized compounds were screened for their antibacterial and antioxidant activities. Antimicrobial studies revealed that 3-(5-(2,5-dimethylphenyl)-1-phenyl-4,5-dihydro-1H-pyrazol-3-yl)-4hydroxy-2H-chromene-2-one 5c showed significant antibacterial activity against Escherichia coli and Pseudomonas Aeruginosa 27853. Furthermore, 3-(5-(aryl)-4,5-dihydro-1H-pyrazol-3-yl)-4-hydroxy-2H-chromene2-ones 4, 5 showed antioxidant activities of different extents with respect to individual compounds as well as to the antioxidant methods. The 3-(5-(phenyl)-4,5-dihydro-1H-pyrazol-3-yl)-4-hydroxy-2H-chromene-2-ones 4a was found to be the most active antioxidant in the series and more active than trolox which makes the investigated complexes a new promising class of antibacterial compounds.
\end{abstract}

Keywords: 4-Hydroxycoumarin, Pyrazole, Antibacterial Activity, Antioxydant Activity

\section{Introduction}

Chalcones are important precursors of flavonoids and isoflavonoids [1]. A large number of chalcones have been prepared by Claisen-Schmidt condensation of aldehydes with methyl ketones under basic conditions [2]. These compounds have shown in vitro antimalarial activity against chloroquine-sensitive and chloroquine-resistant strains of Plasmodium falciparum [3]. Recently authors have reported the synthesis of chalcones under acidic conditions using perchloric acid and acetic acid [4]. The activity of a variety of chalcones as potent tyrosinase inhibitors and antioxidants has been also reported which are, thus, used as new depigmentation agents [5]. Nitrogen heterocycles containing chalcone moiety have been reported as active compounds against herpes simplex virus-1 (HSV-1) and human immunodeficiency virus 1
(HIV-1) [6,7]. This class of compounds also exhibits cytotoxic activity towards leukemia cell lines $[8,9]$. Various other chalcones exhibit insecticidal, antichinoviral, and antipicorniviral properties [10].

On the other hand, coumarins and structurally related compounds have been shown to inhibit replication of HIV and thus exhibit a therapeutic potential [11]. A large number of structurally novel coumarin derivatives have been reported to show substantial cytotoxic and anti-HIV activity both in vitro and in vivo [12,13]. A variety of synthetic coumarins have unique action mechanisms referring to the different stages of HIV replication [14]. Thus, coumarins are important lead compounds for the development of antiviral and/or virucidal drugs against HIV [15-17].

In view of the variety of pharmacological properties exhibited by chalcones, we were prompted to undertake 
the synthesis of new compounds of this class and to study their conversion to other heterocycles which may show different or better physiological activities. We report herein the synthesis of new chalcone derivatives and their conversion to pyrazoles using nitrogen bases. In this regard it is worth stressing that also pyrazoles have been reported to show anti-inflammatory $[18,19]$, cytotoxic [20], insecticidal [21], herbicidal [22], and fungicidal $[23,24]$ activity.

\subsection{Chemistry}

Due to the exceptional reactivity of the acetyl group in 3 -acetylchromone as well as the versatile biological activities of coumarin derivatives, the chalcone 3 was synthesized from 4-hydroxycoumarin (1) under mild basic conditions.

Compound 2 was prepared by reaction of 4-hydroxycoumarine with $\mathrm{POCl}_{3}$ in chloroform in the presence of acetic acid, The resulting compound 2 was then reacted with arylaldehydes to give the (E) the coumarinic chalcones 3, which precipitated out from the hot $\mathrm{MeOH}$ solu- tion after mixing 2 with the corresponding $\mathrm{ArCHO}$ Scheme 1.

3-((2E)-3(aryl) prop-2-enoyl)-2H-chromen-2-one compounds $3 \mathbf{a}-3 \mathbf{e}$ were identified from analysis of their spectroscopic data. The infrared (IR) spectrum of compound 3d showed the coumarin carbonyl groups at $1768 \mathrm{~cm}^{-1}$, in addition to a broad band for the $\mathrm{C}=\mathrm{C}$ group at 1595 $\mathrm{cm}^{-1}$. The ${ }^{1} \mathrm{H}$ NMR spectrum showed trans olefinic protons $\mathrm{H}_{\mathrm{a}}$ and $\mathrm{H}_{\mathrm{b}}$ as ortho-coupled doublets at $8.25(\mathrm{~J}=$ $15.6 \mathrm{~Hz})$ and $6.92(J=15.9 \mathrm{~Hz})$, respectively. The remaining aromatic protons of the aromatic aldehydes and the four protons of the coumarin moiety appeared as a multiplet in the region $\delta 7.25-8.08$.

The ${ }^{13} \mathrm{C}\left\{{ }^{1} \mathrm{H}\right\}$ NMR spectrum of 3d in DMSO- $d_{6}$ showed two downfield signals at ä $147.4 \mathrm{ppm}\left(\mathrm{C}_{4}\right)$ and ä 162.4 ppm (lactone $\mathrm{C}=\mathrm{O}$ ) as well as an up field signal to at ä $55.4 \mathrm{ppm}\left(\mathrm{OCH}_{3}\right)$. The condensation of hydrazines with $\alpha, \beta$-unsaturated carbonyl compounds usually gives pyrazolines [25] activities. Thus, when compound 3 was treated with nitrogen bases such as hydrazine and phenylhydrazine, the pyrazolines $\mathbf{4}$ and $\mathbf{5}$ were obtained, respectively. (Scheme 2)<smiles>CC(=O)c1c(O)c2cc(C=C(C)C)ccc2oc1=O</smiles>

i: $\mathrm{POCl}_{3}, \mathrm{ACOH}$, ii: $\mathrm{CHCl}_{3}$, piperidine, Arylaldehyde

\begin{tabular}{cc}
\hline Compounds 3 & $\mathrm{R}$ \\
\hline 3a & $\mathrm{H}$ \\
3b & $\mathrm{F}$ \\
3c & $2,5 \mathrm{CH}_{3}$ \\
3d & $\mathrm{OCH}_{3}$ \\
3e & $\mathrm{NO}_{2}$ \\
\hline
\end{tabular}

Scheme 1. synthesis of chalcones 3.

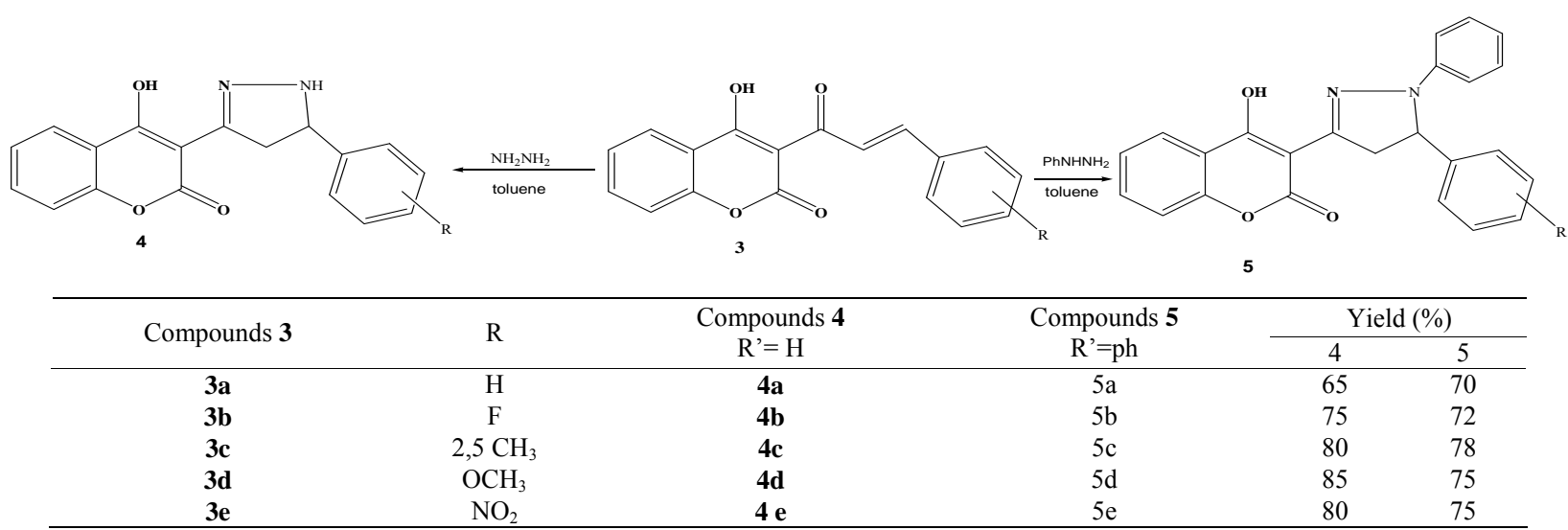

Scheme 2. Synthesis of 3-(5-aryl-4,5-dihydro-1h-pyrazol-3-yl)-4-hydroxy-2h-chromene-2-ones 4, 5. 
All the new 3-(5-aryl-4,5-dihydro-1H-pyrazol-3-yl)-4hydroxy-2H-chromene-2-ones 4, 5 were characterized by IR, ${ }^{1} \mathrm{H},{ }^{13} \mathrm{C}-\mathrm{NMR}$ spectra as well as by NOESY and HMBC 2D-NMR experiments to elucidate their structures and assign completely the structural network of both protons and carbons. The spectral data were in accordance with the proposed structures (see experimental section).

The IR spectrum of $\mathbf{4 d}$ showed broad band at 3207 $\mathrm{cm}^{-1}$ due to the presence of the NH group. A sharp and strong absorption band at $1668 \mathrm{~cm}^{-1}$ indicated a carbonyl group in the compound.

Since chromone carbonyl groups usually appear as sharp absorption bands in the region $1620-1650 \mathrm{~cm}^{-1}$ [26], the band at $1684 \mathrm{~cm}^{-1}$ was assigned to coumarin rather than the chromone carbonyl group.

In addition, the detection of a strong $\mathrm{C}=\mathrm{N}$ stretching band at $1608 \mathrm{~cm}^{-1}$ evidenced the formation of the pyrazole ring. The ${ }^{1} \mathrm{H}$ NMR spectra of $\mathbf{4 d}$ displays a signal at $\delta 4.12 \mathrm{ppm}$ ascribable to the $\mathrm{CH}_{2}$ protons of the pyrazole ring. A characteristic singlet proton signal at $\delta 4.81 \mathrm{ppm}$ was assigned to $\mathrm{CH}$ proton from the pyrazole fragment. In addition, the aromatic protons (both coumarinic and aromatic) are observed between $\delta 6.82$ and $\delta 8.1 \mathrm{ppm}$ (see experimental).

Full assignment of the ${ }^{1} \mathrm{H}$ NMR spectra of $\mathbf{4 d}$ was deduced from the NOESY spectrum. An observed NOE cross peak between $\mathrm{H}-1$ ' and aromatic protons confirms that these two units are located on the same side of the pyrazole ring.

The structure of $\mathbf{4 d}$ was finally elucidated through the analysis of the ${ }^{1} \mathrm{H},{ }^{13} \mathrm{C}$ HMBC spectrum, which correlates the protons at $\delta 4.78 \mathrm{ppm}$ with $\mathrm{C}_{5^{\prime}}(\delta 55.05 \mathrm{ppm})$ and $\mathrm{C}_{2},(\delta 153.3 \mathrm{ppm})$. The aromatic protons correlate with $\mathrm{C}_{5},(\delta 55,05 \mathrm{ppm})$. (Table 1)
Table 1. Correlations between HMBC and NOESY for compound 4d.

\begin{tabular}{ccc}
\hline Proton & HMBC & NOESY \\
H-n & H-n-C-j & H-n-H-j \\
\hline H-1 & $2,2^{\prime}, 5^{\prime}$ & $\mathrm{H}_{\text {arom }}$ \\
H-5 & $1^{\prime}, 7^{\prime}$ & \\
H-arom & $5^{\prime}$ & \\
\hline
\end{tabular}

A mechanistic rationalization for this reaction is straightforward and is provided in Scheme 3.

The first reaction step consists of a nucleophilic attack of the final hydrazine nitrogen atom to the carbonyl function followed by the elimination of water. The intermediate which forms may easily rearrange to afford the corresponding pyrazoles 4,5 .

\subsection{Results and Discussion}

\subsubsection{Electrochemistry}

Electrochemical studies of 3-(5-aryl-4,5-dihydro-1Hpyrazol-3-yl)-4-hydroxy-2H-chromene-2-one, 5, are of interest due to the electron-deficient nature of the pyrazole unit.

Hence, the electrochemical properties of compounds 5a-e, were determined by cyclic voltammetry in $\mathrm{CH}_{3} \mathrm{CN}$ $\left(1 \times 10^{-3} \mathrm{M}\right)$ solutions, using $0.1 \mathrm{M}$ tetrabutylammonium bromide $\left(\mathrm{C}_{4} \mathrm{H}_{12} \mathrm{BrN}\right)$ as the supporting electrolyte. Both platinum and gold were used as working electrodes, $\mathrm{Ag} / \mathrm{AgCl}(0.1 \mathrm{M})$ as the reference electrode, and platinum as the counter electrode. Under these electrochemical conditions, 5 shows a quasi reversible behavior for the first reduction process. This can be deduced from the fact that the cathodic-anodic peak separations (Epc - Epa) are $c a .100 \mathrm{mV}$. The ratio of the peak current intensity for the cathodic and anodic processes is about $0.5-0.7$.

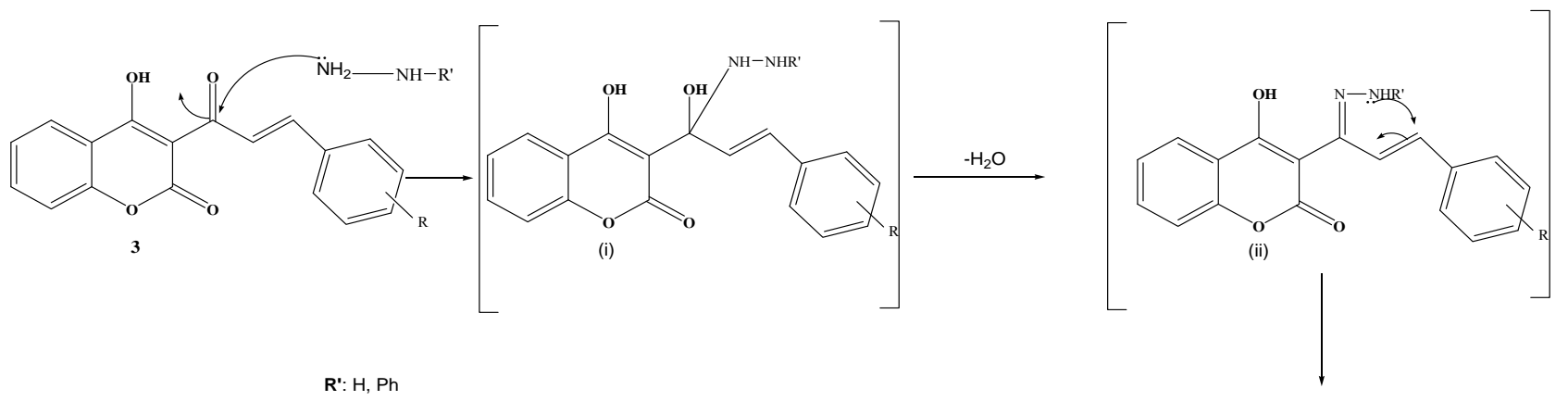<smiles>Cc1c(C2=CNC(c3ccc(I)cc3)C2)c(=O)oc2ccccc12</smiles>

Scheme 3. Proposed mechanism for the synthesis of 4, 5 . 
As expected, the reduction peak potential of the 3-(5-aryl4,5-dihydro-1H-pyrazol-3-yl)-4-hydroxy-2H-chromene2-one 5 are strongly influenced by the para substitutent on the phenylene ring. Compared to the unsubstituted compound 5, the presence of electron donor groups such as the methoxy group shifts the reduction peak potential of 5 to more negative values. The redox behavior of all the new pyrazoles are summarized in Figure 1 All the compounds exhibited one quasireversible redox processes.

For example, compounds 5d showed one quasireversible reduction at $-0.8 \mathrm{~V}$ and $-1.15 \mathrm{~V}$, respectively. We assume that the curve at lower reduction potential may be due to the more electron-deficient dications in the ring system, and the curve at higher reduction potential may be attributed to the redox behavior of the pyrazole unit.

\subsubsection{Antibacterial and Antioxidant Studies}

\subsubsection{Free radical scavenging activity assay}

The free radical scavenging activity of the new 3-(5-aryl4,5-dihydro-1H-pyrazol-3-yl)-4-hydroxy-2H-chromene2-one 4, 5 was tested by utilizing DPPH scavenging [34].

DPPH is a free radical and accepts one electron or one hydrogen radical to become a stable diamagnetic molecule [27]. The reduction capability of DPPH radical was determined by the decrease in absorbance induced by 3-(5-aryl-4,5-dihydro-1H-pyrazol-3-yl)-4-hydroxy-2Hchromene-2-one 4, 5. Briefly, $1.5 \mathrm{ml}$ ethanolic solution of the synthesized compounds $(0.2 \mathrm{mM})$ was added to $1.5 \mathrm{ml}(0.2 \mathrm{mM})$ solution of DPPH radical in ethanol (final concentration of DPPH and synthesized compounds was $0.1 \mathrm{mM}$ ). The mixture was shaken vigorously and allowed to stand for $30 \mathrm{~min}$. After this, the absorbance at $534 \mathrm{~nm}$ was determined and the percentage of scavenging activity was calculated using the following formula:

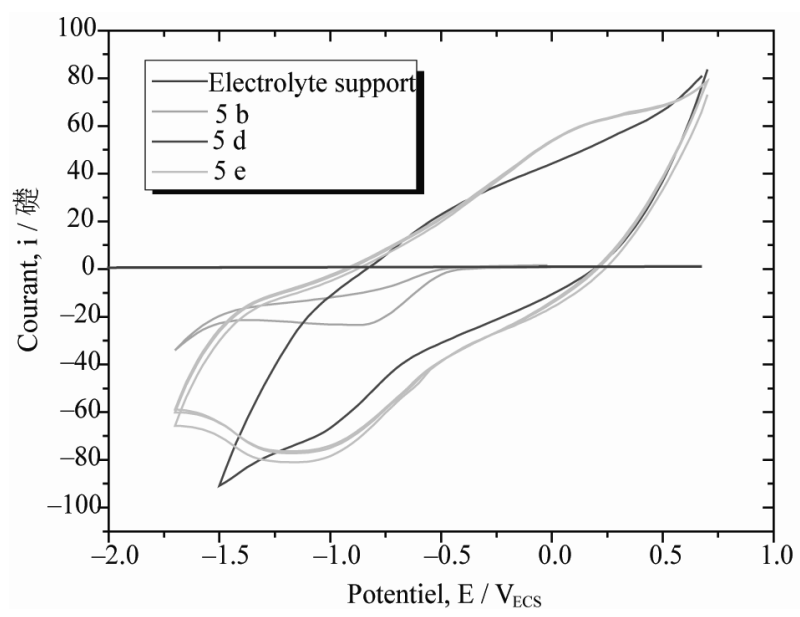

Figure 1 Cyclic voltammograms of compounds $5 \mathrm{~d}, 5 \mathrm{~b}$ and $5 e\left(1 \times 10^{-3} \mathrm{M}\right)$ in $\mathrm{CH}_{3} \mathrm{CN}$, scan rate $100 \mathrm{mV} \cdot \mathrm{s}^{-1}$.
Scavenging activity $=\{[(\mathrm{Ab}+\mathrm{As})-\mathrm{Am}] / \mathrm{Ab}\} \times 100 \%$

$\mathrm{Ab}$ : absorbance of $0.1 \mathrm{mM}$ ethanolic solution of DPPH at $534 \mathrm{~nm}$,

As: absorbance of $0.1 \mathrm{mM}$ ethanolic solution of test compound at $534 \mathrm{~nm}$,

Am: absorbance of ethanolic mixture of the drug and DPPH at $534 \mathrm{~nm}$.

Trolox was used as reference compound. All tests and analyses were done on triplicate and averaged on three samples. The results are given in Scheme 4.

Among the compounds from the 3-(5-aryl-4,5-dihydro1H-pyrazol-3-yl)-4-hydroxy-2H-chromene-2-one 4 series, 4b showed moderate antioxidant activity.

The activity exhibited by the compound $\mathbf{4 e}$ was the highest. In addition the experimental data show that compound 4a scavenges free radical better than Trolox.

According to the experimental results, we notice that increasing the concentration of pyrazole percentage of inhibition reaches $90 \%$ for a concentration about $1 \mu \mathrm{M}$ for all the synthesized products. Thus, we can conclude that substituents on the aryl group do not influence significantly the anti-oxidant activity.

One parameter that has been introduced recently for the interpretation of the results from the DPPH method is the efficient concentration or $\mathrm{EC}_{50}$ value (otherwise called the $\mathrm{IC}_{50}$ value), which is defined as the concentration of substrate that causes $50 \%$ loss of the DPPH activity (color) and corresponds to the endpoint of the titration. In all cases, any residual (yellow) color from the reduced form or any non specific absorbance from the sample should be considered in defining the "endpoint" of the titration, i.e., the $50 \%$ point. Additionally, this $\mathrm{IC}_{50}$ parameter has also the drawback that the higher the antioxidant activity, the lower is the value of $\mathrm{EC}_{50}$.

The $\mathrm{EC}_{50}$ values exhibited by 3-(5-aryl-4,5-dihydro1H-pyrazol-3-yl)-4-hydroxy-2H-chromene-2-one 4, 5 are summarized in the following Table 2.

From inspection of Table 2, it is evident that pyrazoles 4,5 are more active than trolox.

Table 2. The $\mathrm{EC}_{50}$ values exhibited by 3-(5-aryl-4,5-dihydro1H-pyrazol-3-yl)-4-hydroxy-2H-chromene-2-one 4, 5

\begin{tabular}{cc}
\hline Compounds $\mathbf{4 , 5}$ & $\mathrm{CI}_{50}\left(\mu \mathrm{mol} \cdot \mathrm{L}^{-1}\right)$. \\
\hline $\mathbf{4 a}$ & 4,8 \\
$\mathbf{4 b}$ & 5 \\
$\mathbf{4 c}$ & 3,8 \\
$\mathbf{4 d}$ & 4,2 \\
$\mathbf{5 a}$ & 3,8 \\
$\mathbf{5 b}$ & 3,2 \\
$\mathbf{5 c}$ & 2,7 \\
$\mathbf{5 d}$ & 3 \\
trolox & 7,5 \\
\hline
\end{tabular}



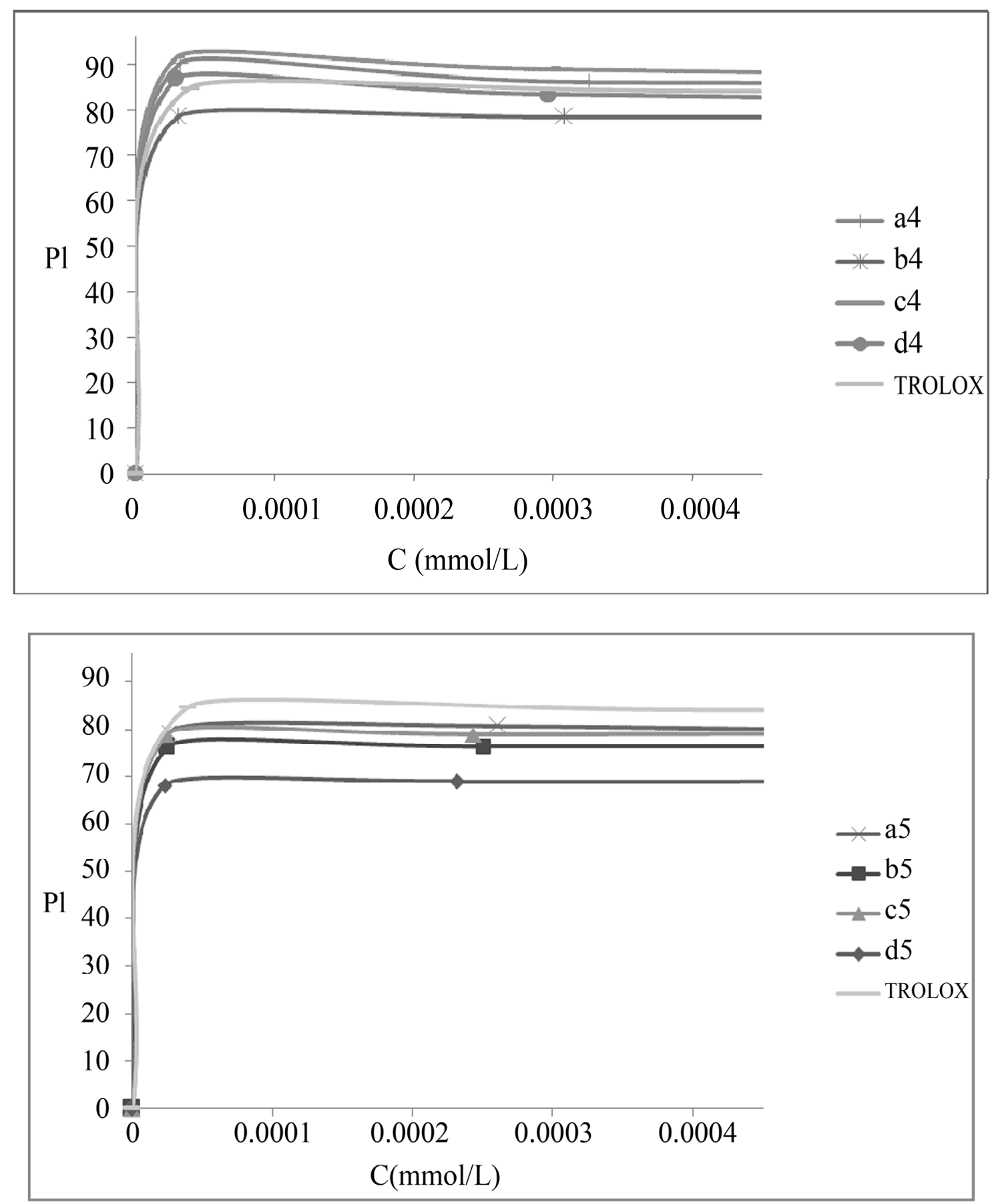

Scheme 4. Scavenging effect on 1,1-diphenyl-2-picrylhydrazyl (DPPH) radical of compounds 4, 5.

\subsubsection{ABTS radical cation decolorization assay}

The potential of 3-(5-aryl-4,5-dihydro-1H-pyrazol-3yl)-4-hydroxy-2H-chromene-2-one 4 to scavenge free radicals was also assessed by checking their ability to quench $\mathrm{ABTS}^{+}$. Scheme 5 depicts the concentrationdependent decolourization of ABTS ${ }^{+}$.

ABTS radical-scavenging activity of 3-(5-aryl-4,5-dihy-
dro-1H-pyrazol-3-yl)-4-hydroxy-2H-chromene-2-one 4 , 5 was determined according to Re et al. 30]. The ABTS ${ }^{+}$. Cation radical was produced by the reaction between $5 \mathrm{ml}$ of $14 \mathrm{mM}$ ABTS solution and $5 \mathrm{ml}$ of $4.9 \mathrm{mM}$ potassium persulfate $\left(\mathrm{K}_{2} \mathrm{~S}_{2} \mathrm{O}_{8}\right)$ solution, stored in the dark at room temperature for $16 \mathrm{~h}$. Before use, this solution was diluted with ethanol to get an absorbance of $0.700 \pm 0.020$ 
at $734 \mathrm{~nm}$. In a final volume of $1 \mathrm{ml}$, the reaction mixture comprised $950 \mu \mathrm{l}$ of ABTS \pm solution and $50 \mu \mathrm{l}$ of the pyrazoles $\mathbf{4}, 5$ at various concentrations. The reaction mixture was homogenized and its absorbance was recorded at $734 \mathrm{~nm}$. Ethanol blanks were run in each assay, and all measurements were done after at least 6 min. Similarly, the reaction mixture of standard group was obtained by mixing 95011 of $\mathrm{ABTS}^{+}$solution and 50 $\mu 1$ of TROLOX. As for the antiradical activity, ABTS sca- venging ability was expressed as $\mathrm{EC}_{50}(<\mathrm{mu}>\mathrm{g} / \mathrm{ml})$. The inhibition percentage of ABTS radical was calculated using the following formula:

$$
\text { ABTS scavenging effect } \%=\left\{\left[\left(\mathrm{A}_{0}-\mathrm{A}_{1}\right)\right] / \mathrm{AO}\right\} \times 100 \%
$$

where $A_{0}$ is the absorbance of the control at $30 \mathrm{~min}$, and A1 is the absorbance of the Sample at $30 \mathrm{~min}$. All samples were analyzed in triplicate.

As shown for DPPH scavenging, these data indicate the higher capacity of 3-(5-aryl-4,5-dihydro-1H-pyrazol3-yl)-4-hydroxy-2H-chromene-2-one 4, 5 to quench $\mathrm{ABTS}^{+}$ as compared to the synthetic antioxidant TROLOX.

The variation of the percentage of inhibition (PI) is almost constant starting from a value of the concentration equal to $1,34 \mathrm{mM}$. In addition, the synthesized products $\mathbf{5}$ have an antioxidant activity better than Trolox. Indeed, the antioxydant capacity seems to be attenuated
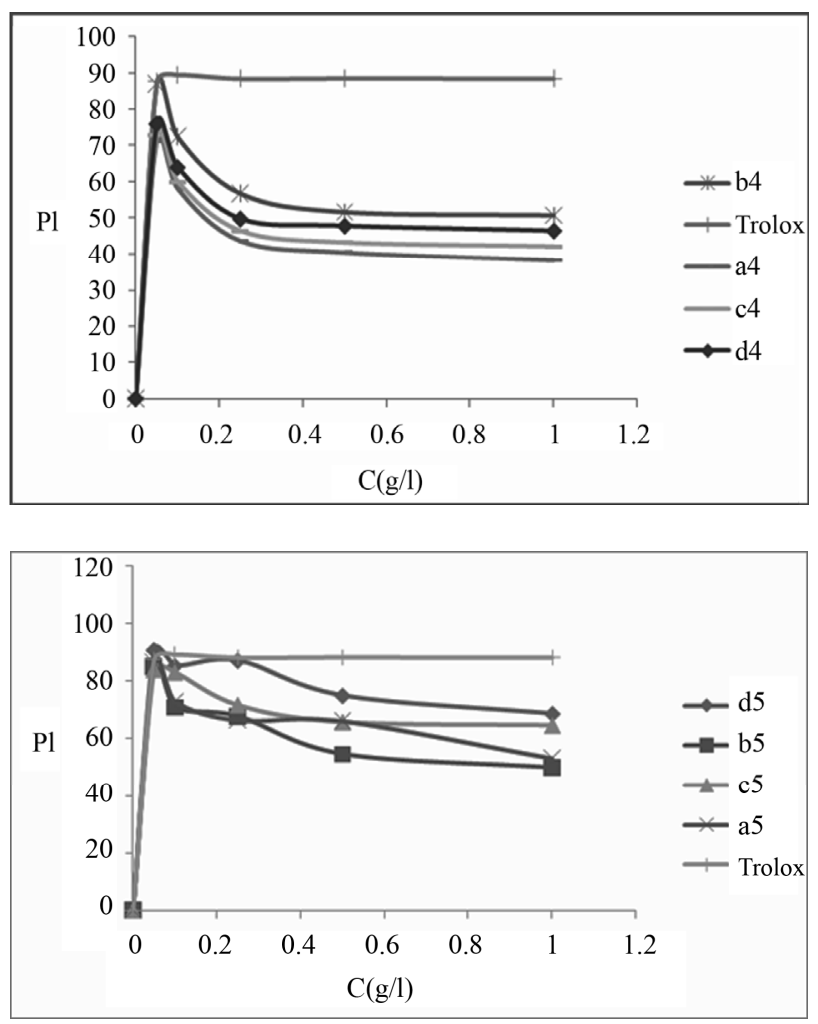

Scheme 5. Scavenging ability on ABTS radical of compounds 4, 5 . when the concentration increases in the medium. This can be explained by the existence of the peroxides sites which are susceptible for oxidizing when the concentration increases. We have just shown that the synthesized pyrazoles derivatives $\mathbf{4}, \mathbf{5}$ have a good antioxidant activity under weak concentration, but it proves to be necessary to determine the reaction time necessary to highlight the antioxidant effect to be able to use these derivatives in pharmay.

The $\mathrm{EC}_{50}$ values exhibited by 3-(5-aryl-4,5-dihydro1H-pyrazol-3-yl)-4-hydroxy-2H-chromene-2-one 4, 5 are summarized in the following Table 3.

The 3-(5-aryl-4,5-dihydro-1H-pyrazol-3-yl)-4-hydroxy2H-chromene-2-one 4, 5 were shown to be efficient antioxidants. They showed higher free radical scavenging activity than Trolox scavenging activities.

These compounds have a remarkable capacity oxidizing which explains their susceptibility to fix free radicals DPPH and ABTS ${ }^{+}$.

\section{Antibacterial Activity}

The antibacterial activity of 3-(5-aryl-4,5-dihydro-1Hpyrazol-3-yl)-4-hydroxy-2H-chromene-2-one 4 was assessed by the agar disk diffusion assay [28] against five human pathogenic bacteria: Gram-positive including Staphylococcus aureus (CIP 7625), Staphylococcus aureus and Gram-negative bacteria including Escherichia coli (ATCC 25922), Pseudomonas aeruginosa (ATCC 27853) (CIP 76110) and Klebsiella pneumonia CIP 104727. The bacterial strains were first grown on Muller Hinton medium at $37^{\circ} \mathrm{C}$ for $24 \mathrm{~h}$ prior to seeding onto the nutrient agar. The antibacterial activity was assessed by measuring the zone of growth inhibition surrounding the discs and compared with the known antibiotic gentamycin. Standard discs of gentamycin (10 UI) served as positive antibiotic controls according to CASFM 2005 guidelines. Discs with $10 \mu \mathrm{l}$ of pure methanol were used as negative controls. The results are given in Table 4 below.

Table 3. The $\mathrm{EC}_{50}$ values exhibited by 3-(5-aryl-4,5-dihydro1H-pérazol-3-yl)-4-hydroxy-2H-chromène-2-one 4, 5.

\begin{tabular}{cc}
\hline Compounds $\mathbf{4 , 5}$ & $\mathrm{CI}_{50}\left(\mathrm{~g} \cdot 1^{-1}\right)$ \\
\hline $\mathbf{4 a}$ & 0.72 \\
$\mathbf{4 b}$ & 0.98 \\
$\mathbf{4 c}$ & 0.78 \\
$\mathbf{4 d}$ & 1.17 \\
$\mathbf{5 a}$ & 0.938 \\
$\mathbf{5 b}$ & 1 \\
$\mathbf{5 c}$ & 0.773 \\
$\mathbf{5 d}$ & 0.72 \\
Trolox & 0.549 \\
\hline
\end{tabular}


Table 4. Antibacterial activity spectrum of compounds 5a-e.

\begin{tabular}{|c|c|c|}
\hline Indicator organism & $\begin{array}{l}\text { inhibition } \\
\text { zone }(\mathrm{mm})\end{array}$ & compounds \\
\hline \multirow{6}{*}{ Staphylococcus aureus (CIP 7625) } & 34 & $5 a$ \\
\hline & 27 & $5 \mathbf{b}$ \\
\hline & 28 & $5 c$ \\
\hline & 33 & 5d \\
\hline & 34 & $5 e$ \\
\hline & $24-28$ & Gentamycin \\
\hline \multirow{6}{*}{ Staphylococcus aureus* } & 26 & $5 a$ \\
\hline & 28 & $5 \mathbf{b}$ \\
\hline & 27 & $5 c$ \\
\hline & 33 & 5d \\
\hline & 34 & $5 e$ \\
\hline & 24 & Gentamycin \\
\hline \multirow{6}{*}{ Escherichia coli ATCC 25922} & 30 & $5 a$ \\
\hline & 27 & $5 \mathbf{b}$ \\
\hline & 35 & $5 c$ \\
\hline & 32 & 5d \\
\hline & 31 & $5 e$ \\
\hline & $22-26$ & Gentamycin \\
\hline \multirow{6}{*}{ Klebsiella pneumonia CIP 104727} & 25 & $5 a$ \\
\hline & 27 & $5 b$ \\
\hline & 31 & $5 c$ \\
\hline & 30 & $5 d$ \\
\hline & 28 & $5 e$ \\
\hline & 21 & Gentamycin \\
\hline \multirow{6}{*}{$\begin{array}{c}\text { PseudomonasAeruginosa } 27853 \\
\text { (CIP 76110) }\end{array}$} & 30 & $5 a$ \\
\hline & 26 & $5 b$ \\
\hline & 34 & $5 c$ \\
\hline & 33 & $5 d$ \\
\hline & 32 & $5 e$ \\
\hline & $15-22$ & Gentamycin \\
\hline
\end{tabular}

The residual antibacterial activity of the compounds was tested by disc diffusion assay against the indicator strain in $\mathrm{LB}$ medium at $28^{\circ} \mathrm{C}$

ATCC: American Type Culture Collection, USA; CIP: Collection de l'Institut Pasteur, Paris, France

LM: Laboratoire de Microbiologie, Centre National de Greffe de Moelle Osseuse, Tunis, Tunisia

Methicillin-resistant clinical isolates

An examination of the data reveals that all the compounds showed antibacterial activity ranging from 25 to $100 \mu \mathrm{g} \mathrm{ml}^{-1}$. The compounds $5 \mathbf{a}$ and $5 \mathbf{e}$ were highly active against all the five organisms employed. Compound 5c was highly active against $E$. coli. From the screened results, it is observed that the presence of methoxy/ $\mathrm{NO}_{2}$ group at the phenyl ring increases the antibacterial activity. The highest activity was found in compound $5 \mathbf{b}$ bearing a methoxy group at 4-position.

\section{Conclusions}

A new versatile synthetic route to 3-(5-aryl-4,5-dihydro1H-pyrazol-3-yl)-4-hydroxy-2H-chromene-2-one 4,5 by the treatment of 4-hydroxycoumarine with different reagents is described. The method is easy, rapid and yielded the title compounds 4, 5 in good yields. The structures of the novel compounds were verified by, IR 1D/2D NMR spectroscopy. All the newly synthesized compounds were screened for their antibacterial and antioxidant activities. Among the screened samples, compounds $\mathbf{5 a}$ and $\mathbf{5 b}$ showed excellent antibacterial activity against $E$. coli. Compounds with 4-phenyl, 4-methoxyphenyl, 4-fluorophenyl and 4-nitrophenyl substituents in the pyrazole ring exhibited higher antioxidant activity than trolox while the pyrazole bearing a $p$-methoxy substituent in the phenyl ring exhibited enhanced antioxidant activity.

\section{Experimental Section}

\subsection{General}

All reactions were magnetically stirred. Commercially available reagents were used without further purification. All chemicals were supplied from Aldrich, Merck andFluka Co. Melting points were determined by open capillary method and were uncorrected.

All reactions were monitored by thin layer chromatography (TLC). Compounds were visualized with UV light at 254 and $365 \mathrm{~nm}$. Melting points were measured on a WRX-1S instrument. Infrared (IR) spectra were recorded with a Perkin-Elmer spectrum one B spectrometer. ${ }^{1} \mathrm{H}$ and ${ }^{13} \mathrm{C}\left\{{ }^{1} \mathrm{H}\right\}$ NMR spectra were recorded on a Varian-Unity spectrometer at $300 \mathrm{MHz}$ using tetramethylsilane (TMS) as an internal standard. Cyclic voltammetry (CV) was performed on a BAS $100 \mathrm{BW}$ electrochemical workstation. All CV measurements were carried out using tetrabutylammonium bromide $\left(\mathrm{C}_{4} \mathrm{H}_{12} \mathrm{BrN}\right)$ as a supporting electrolyte, purging with nitrogen prior to conduct the experiment. Platinum wire (MF-2013) was used as a working electrode, $\mathrm{Ag} / \mathrm{AgCl}$ as a reference electrode, and another platinum wire (MF-1032) as a counter electrode.

\section{3-Acetyl-4-hydroxycoumarin}

To a solution of 4-hydroxy-2H-chromen-2-one (3.0 g, $1.86 \mathrm{mmol})$ in acetic acid $(16 \mathrm{ml})$ phosphorus oxychloride $(5.6 \mathrm{ml})$ was added. The mixture was heated at reflux for $30 \mathrm{~min}$. After cooling to room temperature, the precipitate which separated out was collected by filtration and recrystallized from ethanol to give 3-acetyl-4hydroxy-2Hchromen-2-one as white needles. Yield $2.7 \mathrm{~g}$ (90\%); $\mathrm{Mp}=135^{\circ} \mathrm{C}$. IR spectrum, $v \mathrm{~cm}^{-1}: 3185(\mathrm{OH})$; 1705 (CO); 1700 (O-CO lactone). ${ }^{1} \mathrm{H}$ NMR spectrum $\left(\mathrm{CDCl}_{3}\right) . \delta: 2.72\left(3 \mathrm{H}, \mathrm{s}, \mathrm{CH}_{3}\right) ; 7.98(1 \mathrm{H}, \mathrm{s}, \mathrm{H}-5) ; 7.95$ $\left(1 \mathrm{H}, \mathrm{dd},{ }^{3} J\right.$ 7.8, 8.35, $\left.{ }^{4} J 6.8,1.2 \mathrm{~Hz}, \mathrm{H}-8\right) ; 7.1$ - $7.4(2 \mathrm{H}$, m, H-6 + H-7); 17.7 (1H, s, OH). ${ }^{13} \mathrm{C}\left\{{ }^{1} \mathrm{H}\right\}$ NMR spectrum $\left(\mathrm{CDCl}_{3}\right), \delta: 29.9\left(\mathrm{CH}_{3}\right) ; 178.5(\mathrm{CO}) ; 159.8$ (C-4); 154.6 (C-2); 101.3 (C-3); 115.0 - $136.0\left(\mathrm{C}_{\text {arom }}\right)$. 
General procedure for the preparation of the coumarinic chalcones $4 a-i$

3-acetyl-4-hydroxy-2Hchromen-2-one $(0.031 \mathrm{~mol})$ and the substituted aromatic aldehyde $(0.03 \mathrm{~mol})$ were dissolved in $30 \mathrm{~mL}$ of chloroform. A catalytic amount of piperidine $(0.02 \mathrm{~mol})$ was added and the reaction mixture was refluxed for $1.5 \mathrm{~h}$. The chloroform was removed under vacuum and the residue was washed

3-((2E)-3(phenyl)prop-2-enoyl)-2H-chromen-2-one: 3a Yield 85\%; $\mathrm{mp} 265^{\circ} \mathrm{C}$. IR spectrum, $v \mathrm{~cm}^{-1}: 1490(\mathrm{C}=\mathrm{O})$, $1728(\mathrm{O}-\mathrm{C}-\mathrm{O}), 1529(\mathrm{C}=\mathrm{C}) .{ }^{1} \mathrm{H}$ NMR spectrum $\left(\mathrm{CDCl}_{3}\right)$. $\delta$ ppm: $6.5-8.3\left(\mathrm{~m}, 11 \mathrm{H}, \mathrm{H}_{\text {arom }}, \mathrm{H}_{\text {eth }}\right) ; 18.56(\mathrm{~s}, 1 \mathrm{H}, \mathrm{OH})$. ${ }^{13} \mathrm{CNMR}$ spectrum $\left(\mathrm{CDCl}_{3}\right) . \delta$ ppm: $116.9\left(\mathrm{C}_{3}\right) ; 135.8$ $\left(\mathrm{C}_{2}\right) ; 147.1\left(\mathrm{C}_{4}\right) ; 134.5\left(\mathrm{C}_{\text {ethyl }}\right)$

3-((2E)-3(4-fluorophenyl)prop-2-enoyl)-2H-chromen2-one: $3 b$

Yield $80 \%$; mp $215^{\circ} \mathrm{C}$. IR spectrum, $v \mathrm{~cm}^{-1}: 1494(\mathrm{C}=\mathrm{O})$, $1716(\mathrm{O}-\mathrm{C}-\mathrm{O}), 1531(\mathrm{C}=\mathrm{C}) .{ }^{1} \mathrm{H}$ NMR spectrum $\left(\mathrm{CDCl}_{3}\right.$, $400 \mathrm{MHz}) . \delta$ ppm: $6.51-8.21\left(\mathrm{~m}, 10 \mathrm{H}, \mathrm{H}_{\text {arom+éthyl }}\right) ; 18,4(\mathrm{~s}$, $1 \mathrm{H}, \mathrm{OH}) .{ }^{13} \mathrm{CNMR}$ spectrum $\left(\mathrm{CDCl}_{3}\right) . \delta$ ppm: $100.9\left(\mathrm{C}_{3}\right)$; $154.8\left(\mathrm{C}_{2}\right) ; 166\left(\mathrm{C}_{4}\right) ; 181.5(\mathrm{CO}) ; 136.2\left(\mathrm{C}_{\text {éthyl1 }}\right) ; 131.5$ $\left(\mathrm{C}_{\text {éthyl } 2}\right) ; 116.5-131.51\left(\mathrm{C}_{\text {arom }}\right)$. NMR ${ }^{19} \mathrm{~F}\left(\mathrm{CDCl}_{3}, 400\right.$ $\left.\mathrm{MHz}, \mathrm{t}_{\mathrm{amb}}\right) \mathrm{ppm}:-107.8$

*3-((2E)-3(2, 5-dimethylphenyl)prop-2-enoyl)-2H-chromen-2-one: 3c

Yield 75\%; mp $224^{\circ} \mathrm{C}$. IR spectrum, $v \mathrm{~cm}^{-1}: 1490(\mathrm{C}=\mathrm{O})$, 1720 (O-C-O), $1527(\mathrm{C}=\mathrm{C}) .{ }^{1} \mathrm{H}$ NMR spectrum $\left(\mathrm{CDCl}_{3}\right)$. $\delta$ ppm: 2,41 (s, $\left.1 \mathrm{H}, \mathrm{CH}_{3}\right), 3,21\left(\mathrm{~s}, 3 \mathrm{H}, \mathrm{CH}_{3}\right), 6.82-8.21$ (m, 9H, $\left.\mathrm{H}_{\text {arom+éthy }}\right) ; 13,81(\mathrm{~s}, 1 \mathrm{H}, \mathrm{OH}) .{ }^{13} \mathrm{CNMR}$ spectrum $\left(\mathrm{CDCl}_{3}\right) . \delta$ ppm: $91.4\left(\mathrm{C}_{3}\right) ; 135.8\left(\mathrm{C}_{2}\right) ; 161.4\left(\mathrm{C}_{4}\right) ; 139.1$ $\left(\mathrm{C}_{\text {éthyl }}\right), 134.1\left(\mathrm{C}_{\text {éthy }}\right) ; 116.4-133.2\left(\mathrm{C}_{\text {rom }}\right), 176.2(\mathrm{CO})$

*3-((2E)-3(4-methoxyphenyl) prop-2-enoyl)-2H-chromen2-one: $3 d$

Yield 75\%; mp $194^{\circ} \mathrm{C}$. IR spectrum, $v \mathrm{~cm}^{-1}: 1494(\mathrm{C}=\mathrm{O})$, 1708 (O-C-O), $1595(\mathrm{C}=\mathrm{C}) .{ }^{1} \mathrm{H}$ NMR spectrum $\left(\mathrm{CDCl}_{3}\right)$. $\delta$ ppm: $3.84\left(\mathrm{~s}, 3 \mathrm{H}, \mathrm{OCH}_{3}\right) ; 6.92(\mathrm{~d}, 1 \mathrm{H}, \mathrm{CH}) ; 8.25(\mathrm{~d}, 1 \mathrm{H}$, $\mathrm{CH}) ; 7.25-8.08\left(\mathrm{~m}, 8 \mathrm{H}, \mathrm{H}_{\text {arom }}\right) ; 18.05(\mathrm{~s}, 1 \mathrm{H}, \mathrm{OH})$. ${ }^{13} \mathrm{CNMR}$ spectrum $\left(\mathrm{CDCl}_{3}\right) . \delta$ ppm: $55.4\left(\mathrm{OCH}_{3}\right) ; 114.4$ $\left(\mathrm{C}_{3}\right) ; 116.8-131.3\left(\mathrm{C}_{\text {arom }}\right) ; 135.6\left(\mathrm{C}_{2}\right) ; 147.48\left(\mathrm{C}_{4}\right) ; 162.4$ (CO).

*3-((2E)-3(4-nitrophenyl)prop-2-enoyl)-2H-chromen2-one: 3e

Yield $72 \%$; mp $194^{\circ} \mathrm{C}$. IR spectrum, $v \mathrm{~cm}^{-1}: 1489(\mathrm{C}=\mathrm{O})$, $1712(\mathrm{O}-\mathrm{C}-\mathrm{O}), 1535(\mathrm{C}=\mathrm{C}) .{ }^{1} \mathrm{H}$ NMR spectrum $\left(\mathrm{CDCl}_{3}\right) . \delta$ ppm: $7.1-8.6\left(\mathrm{~m}, 1 \mathrm{OH}, \mathrm{H}_{\text {arom+ethyl }}\right) ; 18.4(\mathrm{~s} 1$, $\mathrm{H}, \mathrm{OH}) .{ }^{13} \mathrm{CNMR}$ spectrum $\left(\mathrm{CDCl}_{3}\right) . \delta$ ppm: $98.7\left(\mathrm{C}_{3}\right)$; $151.8\left(\mathrm{C}_{2}\right) ; 178.7\left(\mathrm{C}_{4}\right) ; 182.5(\mathrm{CO}) ; 151.86\left(\mathrm{C}_{\text {ethyl1 }}\right)$; $122.5\left(\mathrm{C}_{\text {ethyl2 }}\right)$.
3-(5-(phenyl)-4,5-dihydro-1H-pyrazol-3-yl)-4-hydroxy -2H-chromene-2-ones: 4a

Yield $65 \% ; \mathrm{mp} 234^{\circ} \mathrm{C}$. IR spectrum, $v \mathrm{~cm}^{-1}: 1683(\mathrm{C}=\mathrm{O}$ lactone), $1608(\mathrm{C}=\mathrm{N}), 3230(\mathrm{NH}) .{ }^{1} \mathrm{H}$ NMR spectrum $\left(\right.$ DMSO- $\left.d_{6}, 300 \mathrm{MHz}, \mathrm{t}_{\mathrm{amb}}\right) \delta$ ppm: $1.75\left(\mathrm{~d}, 2 \mathrm{H}, \mathrm{CH}_{2}\right)$, $3.74(\mathrm{t}, 1 \mathrm{H}, \mathrm{CH}), 6,82-7,27$ (m, 9H, Harom). ${ }^{13} \mathrm{CNMR}$ spectrum (DMSO- $\left.d_{6}, 75 \mathrm{MHz}, \mathrm{t}_{\text {amb }}\right) \delta$ ppm: $40,6\left(\mathrm{CH}_{2}\right)$ 49,5 (CH), 91,1 $\left(\mathrm{C}_{3}\right) ; 158,6\left(\mathrm{C}_{2}\right) ; 166,4\left(\mathrm{C}_{4}\right) ; 155,7(\mathrm{C}=$ $\mathrm{N}), 121,5-127,1$ (Carom). with methanol

3-(5-(4-fluorophenyl)-4,5-dihydro-1H-pyrazol-3-yl)-4hydroxy-2H-chromene-2-ones: $4 \mathrm{~b}$

Yield $70 \% ; \mathrm{mp} 220^{\circ} \mathrm{C}$. IR spectrum, $v \mathrm{~cm}^{-1}: 1668(\mathrm{C}=\mathrm{O}$ lactone), $1612(\mathrm{C}=\mathrm{N}), 3192(\mathrm{NH}) .{ }^{1} \mathrm{H}$ NMR spectrum $\left(\mathrm{DMSO}-d_{6}, 300 \mathrm{MHz}, \mathrm{t}_{\mathrm{amb}}\right) \delta$ ppm: $1,76\left(\mathrm{~d}, 2 \mathrm{H}, \mathrm{CH}_{2}\right)$, $3.64(\mathrm{t}, 1 \mathrm{H}, \mathrm{CH}), 6.79-7.35\left(\mathrm{~m}, 8 \mathrm{H}\right.$, Harom) ${ }^{13} \mathrm{CNMR}$ spectrum (DMSO- $\left.d_{6}, 75 \mathrm{MHz}, \mathrm{t}_{\mathrm{amb}}\right) \delta$ ppm: $40.2\left(\mathrm{CH}_{2}\right)$ $48.7(\mathrm{CH}), 91.1\left(\mathrm{C}_{3}\right) ; 158.5\left(\mathrm{C}_{2}\right) ; 166.7\left(\mathrm{C}_{4}\right) ; 155.2$ $(\mathrm{C}=\mathrm{N}), 120.8-128.3$ (Carom). NMR ${ }^{19} \mathrm{~F}$ (DMSO- $d_{6}, 300$ $\mathrm{MHz}, \mathrm{t}_{\mathrm{amb}}$ ) ppm: -139.26

3-(5-(2,5-dimethylphenyl)-4,5-dihydro-1H-pyrazol-3yl)-4-hydroxy-2H-chromene-2-ones: $4 \mathrm{c}$

Yield $80 \%$; $\mathrm{mp} 252^{\circ} \mathrm{C}$. IR spectrum, $v \mathrm{~cm}^{-1}: 1683(\mathrm{C}=\mathrm{O}$ lactone), $1606(\mathrm{C}=\mathrm{N}), 3230(\mathrm{NH}) .{ }^{1} \mathrm{H}$ NMR spectrum (DMSO- $\left.d_{6}, 300 \mathrm{MHz}, \mathrm{t}_{\mathrm{amb}}\right) \delta$ ppm: $1.68\left(\mathrm{~d}, 2 \mathrm{H}, \mathrm{CH}_{2}\right)$, $3,68(\mathrm{t}, 1 \mathrm{H}, \mathrm{CH}), 2,34\left(\mathrm{~s}, 6 \mathrm{H}, 2 \mathrm{CH}_{3}\right), 6.85-7.32(\mathrm{~m}$, Harom). ${ }^{13} \mathrm{CNMR}$ spectrum (DMSO- $d_{6}, 75 \mathrm{MHz}, \mathrm{t}_{\mathrm{amb}}$ ) $\delta$ ppm: $18.6\left(\mathrm{CH}_{3}\right), 24.5\left(\mathrm{CH}_{3}\right), 40.2\left(\mathrm{CH}_{2}\right), 42.6(\mathrm{CH})$, $91.7\left(\mathrm{C}_{3}\right) ; 158.4\left(\mathrm{C}_{2}\right) ; 167.6\left(\mathrm{C}_{4}\right) ; 155.7(\mathrm{C}=\mathrm{N}), 121.7$ 132.8 (Carom).

3-(5-(4-methoxyphényl)-4,5-dihydro-1H-pyrazol-3-yl) -4-hydroxy-2H-chromene-2-ones: 4d

Yield $85 \% ; \mathrm{mp} 210^{\circ} \mathrm{C}$. IR spectrum, $v \mathrm{~cm}^{-1}: 1668(\mathrm{C}=\mathrm{O}$ lactone), $1608(\mathrm{C}=\mathrm{N}), 3207(\mathrm{NH}) .{ }^{1} \mathrm{H}$ NMR spectrum $\left(\mathrm{DMSO}-d_{6}, 300 \mathrm{MHz}, \mathrm{t}_{\mathrm{amb}}\right) \delta$ ppm: $3.84\left(\mathrm{~s}, 3 \mathrm{H}, \mathrm{OCH}_{3}\right)$, $6.82-8.1\left(\mathrm{~m}, 8 \mathrm{H}, \mathrm{H}_{\text {arom }}\right), 4.12\left(\mathrm{~d}, 2 \mathrm{H}, \mathrm{CH}_{2}\right), 4,81(\mathrm{t}, 1 \mathrm{H}$, $\mathrm{CH}) .{ }^{13} \mathrm{CNMR}$ spectrum (DMSO- $\left.d_{6}, 75 \mathrm{MHz}, \mathrm{t}_{\mathrm{amb}}\right) \delta$ ppm: $58.2\left(\mathrm{OCH}_{3}\right), 55.0(\mathrm{CH}), 43.7\left(\mathrm{CH}_{2}\right), 91.4\left(\mathrm{C}_{3}\right)$; $158.7\left(\mathrm{C}_{2}\right) ; 161.6\left(\mathrm{C}_{4}\right) ; 153.3(\mathrm{C}=\mathrm{N}), 113.8-133.4$ (Carom).

3-(5-(phenyl)-1-phenyl-4,5-dihydro-1H-pyrazol-3-yl)4-hydroxy-2H-chromene-2-one:5a

Yield $70 \%$; $\mathrm{mp} 230^{\circ} \mathrm{C}$. IR spectrum, $v \mathrm{~cm}^{-1}: 1668(\mathrm{C}=\mathrm{O}$ lactone), $1608(\mathrm{C}=\mathrm{N}), 3110(\mathrm{NH}) .{ }^{1} \mathrm{H}$ NMR spectrum $\left(\right.$ DMSO- $\left.d_{6}, 300 \mathrm{MHz}, \mathrm{t}_{\mathrm{amb}}\right) \delta$ ppm: $1.65\left(\mathrm{~d}, 2 \mathrm{H}, \mathrm{CH}_{2}\right)$, $3.75(\mathrm{t}, 1 \mathrm{H}, \mathrm{CH}), 6.42-7.35$ (m Harom). ${ }^{13} \mathrm{CNMR}$ spectrum (DMSO- $\left.d_{6}, 75 \mathrm{MHz}, \mathrm{t}_{\mathrm{amb}}\right) \delta$ ppm: $36.4\left(\mathrm{CH}_{2}\right)$ $54.8(\mathrm{CH}), 92.3\left(\mathrm{C}_{3}\right) ; 159.7\left(\mathrm{C}_{2}\right) ; 167.8\left(\mathrm{C}_{4}\right) ; 158.1$ $(\mathrm{C}=\mathrm{N}), 113.5$ - 133.1 (Carom). 
3-(5-(4-fluorophenyl)-1-phenyl-4,5-dihydro-1H-pyraz ol-3-yl)-4-hydroxy-2H-chromene-2-one: $\mathbf{5 b}$

Yield 72\%; mp $226^{\circ} \mathrm{C}$. IR spectrum, $v \mathrm{~cm}^{-1}: 16681683$ $(\mathrm{C}=\mathrm{O}$ lactone $), 1606(\mathrm{C}=\mathrm{N}), 3230(\mathrm{NH}) .{ }^{1} \mathrm{H}$ NMR spectrum (DMSO- $\left.d_{6}, 300 \mathrm{MHz}, \mathrm{t}_{\mathrm{amb}}\right) \delta$ ppm: $1.62(\mathrm{~d}, 2 \mathrm{H}$, $\left.\mathrm{CH}_{2}\right), 3.65(\mathrm{t}, 1 \mathrm{H}, \mathrm{CH}), 6.35-7.45$ (m Harom). ${ }^{13} \mathrm{CNMR}$ spectrum (DMSO- $\left.d_{6}, 75 \mathrm{MHz}, \mathrm{t}_{\mathrm{amb}}\right) \delta$ ppm: $35.3\left(\mathrm{CH}_{2}\right)$ $52.7(\mathrm{CH}), 92.1\left(\mathrm{C}_{3}\right) ; 159.2\left(\mathrm{C}_{2}\right) ; 167.8\left(\mathrm{C}_{4}\right) ; 152.6(\mathrm{C}=\mathrm{N})$, 120.5 - 134.1 (Carom). NMR ${ }^{19} \mathrm{~F}$ (DMSO- $d_{6}, 300 \mathrm{MHz}$, $\left.\mathrm{t}_{\mathrm{amb}}\right) \mathrm{ppm}:-129,42$

\section{3-(5-(2,5-dimethylphenyl)-1-phenyl-4,5-dihydro-1H-p} yrazol-3-yl)-4-hydroxy-2H-chromene-2-one: $5 \mathrm{c}$

Yield $78 \%$; $\mathrm{mp} 265^{\circ} \mathrm{C}$. IR spectrum, $v \mathrm{~cm}^{-1}: 1681(\mathrm{C}=\mathrm{O}$ lactone), $1608(\mathrm{C}=\mathrm{N}), 3220(\mathrm{NH}) .{ }^{1} \mathrm{H}$ NMR spectrum $\left(\right.$ DMSO-d $\left._{6}, 300 \mathrm{MHz}, \mathrm{t}_{\mathrm{amb}}\right) \delta$ ppm: 1,63 (d, 2H, $\left.\mathrm{CH}_{2}\right)$, $3.68(\mathrm{t}, 1 \mathrm{H}, \mathrm{CH}), 6.35-7.68$ (m Harom). ${ }^{13} \mathrm{CNMR}$ spectrum (DMSO- $\left.d_{6}, 75 \mathrm{MHz}, \mathrm{t}_{\mathrm{amb}}\right) \delta$ ppm: $35.3\left(\mathrm{CH}_{2}\right)$ $52.8(\mathrm{CH}), 92.1\left(\mathrm{C}_{3}\right) ; 158.8\left(\mathrm{C}_{2}\right) ; 168.4\left(\mathrm{C}_{4}\right) ; 159.6$ $(\mathrm{C}=\mathrm{N}), 126.5$ - 142.1 (Carom).

\section{3-(5-(4-methoxyphenyl)-1-phenyl-4,5-dihydro-1H-pyr azol-3-yl)-4-hydroxy-2H-chromene-2-one: $5 \mathrm{~d}$}

Yield $75 \%$; $\mathrm{mp} 216^{\circ} \mathrm{C}$. IR spectrum, $v \mathrm{~cm}^{-1}: 1681(\mathrm{C}=\mathrm{O}$ lactone), $1608(\mathrm{C}=\mathrm{N}), 3234(\mathrm{NH}) .{ }^{1} \mathrm{H}$ NMR spectrum $\left(\mathrm{DMSO}-d_{6}, 300 \mathrm{MHz}, \mathrm{t}_{\mathrm{amb}}\right) \delta$ ppm: $1.62\left(\mathrm{~d}, 2 \mathrm{H}, \mathrm{CH}_{2}\right)$, $3.68(\mathrm{t}, 1 \mathrm{H}, \mathrm{CH}), 3.78\left(\mathrm{~s}, 3 \mathrm{H}, \mathrm{CH}_{3}\right), 6.47-7.42(\mathrm{~m}$ Harom). ${ }^{13} \mathrm{CNMR}$ spectrum (DMSO- $d_{6}, 75 \mathrm{MHz}, \mathrm{t}_{\mathrm{amb}}$ ) $\delta$ ppm: $32.4\left(\mathrm{CH}_{2}\right) 51.4(\mathrm{CH}), 55.8\left(\mathrm{OCH}_{3}\right), 93.3\left(\mathrm{C}_{3}\right)$; $156.4\left(\mathrm{C}_{2}\right) ; 167.3\left(\mathrm{C}_{4}\right) ; 152.5(\mathrm{C}=\mathrm{N}), 113.4-132.6$ (Carom).

\section{References}

[1] F. Aqil and I. Ahmad, "Rapid and Accurate Species-Specific Detection of Phytophthora Infestans through Analysis of Its Regions in Its rDNA," Journal of Microbiology and Biotechnology, Vol. 19, No. 6, 2000, pp. 653-657.

[2] A. W. Bauer, W. M. M. Kirby, J. C. Sherris and M. Turch, "Antibiotic Susceptibility Testing by a Standardized Single Disk Method," American Journal of Clinical Pathology, Vol. 45, No. 5, 1998, pp. 493-496.

[3] O. Bruno, A. Ranise, F. Bonadavalli, P. Schenone, M. D'Amico, W. Felipplli, A. Filippelli and F. Rossi, "3,5Diphenyl-1H-Pyrazole Derivatives. XI. N-Aryl-5(3)Phenyl-4-(3,5-Diphenyl-1-Pyrazolyl)-3(5)-Pyrazole Amines, 5-Substituted 4,5-Dihydro-3-Phenyl-4-(3,5-Diphenyl -1-Pyrazolyl)-1H-Pyrazoles and 2,6-Disubstituted 1,6-Dihydro-4-Phenyl-5-(3,5-Diphenyl-1-Pyrazolyl)Pyrimidines with Antipyretic, Anti-Inflammatory and Other Activities," Farmaco, Vol. 48, No. 4, 1998, pp. 949-966

[4] J. R. Dimmock, S. K. Raghavan, et al., "Antileukemic Evaluation of Some Mannich Bases Derived from 2Arylidene-1,3-Diketones," European Journal of Medicinal
Chemistry, Vol. 18, No. 4, 1998, pp. 248-254.

[5] H. R. Eisenhauer and K. P. Link, " Studies on 4-HydroxyCoumarins. XIII. The Mechanism for the Reaction of 4Hydroxycoumarin with Aliphatic Acid Chlorides," Journal of the American Chemical Society, Vol. 75, No. 9, 1953, pp. 2044-2050.

doi:10.1021/ja01105a006

[6] A. A. El-Barbary, A. I. Khodair, E. B. Pederson and C. Nielsen, "S-Glucosylated Hydantoins as New Antiviral agents," Journal of Medicinal Chemistry, Vol. 37, No. 1, 1994, pp. 73-77. doi:10.1021/jm00027a009

[7] E. S. M. El-khawass and A. E. Bistawroos, "Synthesis and Biological Activity of Heterocycles from Chalcone," Medicinal Chemistry Research, Vol. 17, No. 2-7, 2008, pp. 318-325

[8] H. I. El-Subbagh, S. M. Abu-Zaid, M. A. Mahran, F. A. Badaria, Al-Obaid," Synthesis and Biological Evaluation of Certain $\alpha, \beta$-Unsaturated Ketones and Their Corresponding Fused Pyridines as Antiviral and Cytotoxic Agents," Journal of Medicinal Chemistry, Vol. 43, No. 15, 2000, pp. 2915-2921. doi:10.1021/jm000038m

[9] E. O. Nuzum, P. J. Rosenthal and J. H. Mckerrow, "In Vitro Antimalarial Activity of Chalcones and Their Derivatives," Journal of Medicinal Chemistry, Vol. 38, No. 26, 1995, pp. 5031-5037. doi:10.1021/jm00026a010

[10] A. Nayak and A. S. Mittra, "4,4-Bis-5-Pyrazolones and Their 4,4-Unsaturated Products for Possible Use as Fungicides," Journal of the Indian Chemical Society, Vol. 57, 1980, pp. 643-649

[11] N. Marquez, R. Sancho, L. M. Bedoya, J. Alcamy, J. L. Lopez-Perez, A. S. Feliciano, B. L. Fiebich and E. Munoz, "Mesuol, a Natural Occurring 4-Phenylcoumarin, Inhibits HIV-1 Replication by Targeting the NF- $\kappa$ B Pathway," Antiviral Research, Vol. 66, No. 2-3, 2005, pp. 137-143. doi:10.1016/j.antiviral.2005.02.006

[12] C. Spino, M. Dodier and S. Sotheeswaran, "Anti-HIV Coumarins from Calophyllum Seed Oil," Bioorganic \& Medicinal Chemistry Letters, Vol. 8, No. 24, 1998, pp. 3475-3481. doi:10.1016/S0960-894X(98)00628-3

[13] S. Thaisrivongs, K. D. Watenpaugh, W. J. Howe, et al., "Structure-Based Design of Novel HIV Protease Inhibitors: Carboxamide-Containing 4-Hydroxycoumarins and 4-Hydroxy-2-Pyrones as Potent Nonpeptidic Inhibitors," Journal of Medicinal Chemistry, Vol. 38, No. 18, 1995, pp. 3624-3630. doi:10.1021/jm00018a023

[14] D. Yu, M. Suzuki, L. Xie, S. L. Morris-Natschke and K. H. Lee, "Recent Progress in the Development of Coumarin Derivatives as Potent Anti-HIV Agents," Medicinal Research Reviews, Vol. 23, No. 3, 2003, pp. 322-328. doi:10.1002/med.10034

[15] J. W. Erickson and S. K. Burt, "Structural Mechanisms of HIV Drug Resistance," Annual Review of Pharmacology and Toxicology, Vol. 36, 1996, pp. 545-571. doi:10.1146/annurev.pa.36.040196.002553

[16] I. Kostova, S. Raleva, P. Genova and R. Argirova, "Structural Features of Antitumor Titanium Agents and Related Compounds," Bioinorganic Chemistry and Appli- 
cations, Vol. 3, No. 3-4, 2005, pp. 317-329. doi:10.1155/BCA.2005.317

[17] A. J. Vlietinck, T. de Bruyne, S. Apers and L. A. Pieters, "Plant-Derived Leading Compounds for Chemotherapy of Human Immunodeficiency Virus (HIV) Infection", Medicinal Chemistry Research, Vol. 64, 1998, pp. 97102.

[18] J. B. Harborne and T. J. Mabry, "Flavonoid Chemistry of chenopodium fremontii. Infraspecific Variation and Systematic Implications at the Interspecific Level," Chemical Abstracts, Vol. 119, pp. 180774-180776.

[19] K. Kostka, "Chromone Derivatives. VI. Reaction of Phenylhydrazine with Chromone and x-Formyl-o-HydroXyacetophenone," Polish Journal of Chemistry, Vol. 47, 1973, pp. 305-313

[20] E. O. Nuzum, P. J. Rosenthal and J. H. Mckerrow, "In Vitro Antimalarial Activity of Chalcones and Their Derivatives," Journal of Medicinal Chemistry, Vol. 38, No. 26, 1995, pp. 5031-5037. doi:10.1021/jm00026a010

[21] A. Nayak and A. S. Mittra "4,4-Bis-5-Pyrazolones and Their 4,4-Unsaturated Products for Possible Use as Fungicides," Journal of the Indian Chemical Society, Vol. 57, 1980, pp. 643-649

[22] O. Nerya, R. Musa, S. Khatib, S. Tamir, Vaya, "Chalcones as Potent Tyrosinase Inhibitors: The Effect of Hydroxyl Positions and Numbers," Phytochemistry, Vol. 65, No. 10, 2004, pp. 1389-1395.

doi:10.1016/j.phytochem.2004.04.016

NOESY: Nuclear Overhauser effect spectroscopy

HMBC: Heteronuclear Multiple Bond Correlation experiment
[23] Z. N. Siddiqui, G. Khuwaja and M. Asad, "Synthesis of Novel Heterocycles from 3-(3-Alkyl-5-Mercapto-1,2,4Triazolyliminomethyl) Chromones," Heterocyclic Commun, Vol. 12, No. 6, 2006, pp. 443-448

[24] L. Santana, E. Uriarte, L. via Dalla and O. Gia, "A New Benzoangelicin with Strong Photobiological Activity," Bioorganic \& Medicinal Chemistry Letters, Vol. 10, No. 6, 2000, pp. 135-137. doi:10.1016/S0960-894X(99)00640-X

[25] R. H. Wiley and C. H. Jarboe, "Synthesis of Pyrazolines by the Reactions of $\alpha, \beta$-enones with Diazomethane and Hydrazines," Chemistry of Heterocyclic Compounds, Vol. 33, No. 6, 1997, pp. 647-659, doi:10.1007/BF02291794

[26] K. C. Fylaktakidou, D. J. Hadjipavlou-Litina, K. E. Litinas and D. N. Nicolaides, "Natural and Syntheticcoumarin Derivatives with Anti-Inflammatory and Antioxidant Activity," Current Pharmaceutical Design, Vol. 10, No. 6, 2004, pp. 3813-3833

[27] S. Kirkiachiarian, R. Bakhchinian, H. Chidiak, M. Mazmanian and C. Planche, "Two New Flavonoids and Other Constituents in Licorice Root; Their Relative Astringency and Radical Scavenging Effects," Annales Pharmaceutiques Françaises, Vol. 57, No. 5, 1999, pp. 251259.

[28] J. R. Soares, T. C. P. Dins, A. P. Cunha and L. M. Ameida, "Antioxidant Activity of Some Extracts of Thymus Zygis," Free Radical Research, Vol. 26, No. 5, 1997, pp. 469-476. doi:10.3109/10715769709084484 